\title{
PERBEDAAN KADAR RESISTIN PADA OBES DENGAN RESISTENSI INSULIN DAN OBES TANPA RESISTENSI INSULIN
}

\author{
Erlina Marfianti 1
}

\begin{abstract}
Resistin is an adipocytokine that secreted from adipose tissue, resistin level serum increased in obese patients. Resistin has important biological activity on glucose and lipid metabolism, and can affect insulin resistance. Previous study suggested that high level resistin can induce insulin resistance and has contribution to impaired insulin sensitivity. The Objective of this study is to know differences of resistin level in obese with insulin resistance and obese without insulin resistance. This is a cross sectional study with obesity patients recruited from General Check Up and Endorinology outpatients clinic Sardjito General Hospital Yogyakarta. Obese patients are subjects with body mass index $(B M I) \geq 25 \mathrm{~kg} / \mathrm{m}^{2}$. Insulin resistance was assessed using HOMA-IR (homeostasis model assessment insulin resistance), formula calculated from fasting insulin and glucose levels. Resistin was measured with ELISA technique. Differences of obese with insulin resistance and obese without insulin resistance analyze using Mann Whitney $U$ test. There was 48 subjects analyzed in this study, 24 obese patients with insulin resistance and 24 obese patients without insulin resistance. Mean of resistin level was higher in obese subject with insulin resistance than without insulin resistance, but there was no significant $(27,65 \pm 14,44 \mathrm{ng} / \mathrm{ml} \mathrm{vs}$ $23,99 \pm 12,45 \mathrm{ng} / \mathrm{ml}, \mathrm{p}=0,37$ ). From this research, it can be concluded that Resistin level in obese with insulin resistance higher than obese without insulin resistance, but no significant.
\end{abstract}

Keywords: Resistin-Insulin Resistance-obese

\begin{abstract}
Abstrak
Resistin merupakan salah satu adipositokin yang disekresi oleh jaringan adiposa, yang kadarnya meningkat pada obesitas. Resistin mempunyai aktivitas biologik yang penting dalam metabolisme glukosa dan lipid, dan erat kaitannya dengan kejadian resistensi insulin. Beberapa penelitian terdahulu mendukung bahwa kadar resistin tinggi menginduksi resistensi insulin dan berkontribusi pada kegagalan sensitivitas insulin. Tujuan penelitian ini hádala untuk mengetahui perbedaan kadar resistin serum pada obes dengan resistensi insulin dan pada obes tanpa resistensi insulin. Penelitian dilakukan secara potong lintang pada pasien obesitas di poliklinik General C heck Up dan poliklinik endokrin RSUP Dr. Sardjito Yogyakarta. O besitas dinilai dengan indeks massa tubuh $\geq 25 \mathrm{~kg} / \mathrm{m}^{2}$. Resistensi insulin dinilai dengan menggunakan perhitungan indeks HOMA-IR (homeostasis model assesment insulin resistance) yang didapat dari kadar insulin puasa dan kadar gula darah. Pengukuran kadar resistin dengan menggunakan teknik ELISA. Perbedaan kadar resistin pada obes dengan resistensi insulin dan obes tanpa resistensi insulin dianalisa dengan uji Mann Whitney $U$. Didapatkan 56 subyek penelitian yang dianalisis, terdiri dari 24 pasien obes dengan resistensi insulin dan 24 pasien obes tanpa resistensi insulin. Rerata kadar resistin lebih tinggi pada kelompok resistensi insulin, tetapi secara statistik tidak bermakna $(27,65 \pm 14,44 \mathrm{ng} / \mathrm{ml}$ vs $23,99 \pm 12,45 \mathrm{ng} / \mathrm{ml}, \mathrm{p}=0,37)$. Dari hasil penelitian ini dapat disimpulakan bahwa kadar resistin pada obes dengan resistensi insulin kesan lebih tinggi daripada obes tanpa resistensi insulin, tetapi secara statistik tidak berbeda bermakna.
\end{abstract}

Kata kunci: Resistin-Resistensi insulin-obes

\footnotetext{
${ }^{1}$ Departemen IImu Penyakit Dalam Fakultas Kedokteran Universitas Islam Indonesia
} 


\section{PENDAHULUAN}

Obesitas merupakan masalah global di negara-negara maju ataupun negara berkembang. Prevalensi obesitas meningkat secara dramatik pada beberapa dekade terakhir. Prevalensi obesitas meningkat secara cepat berkaitan dengan perubahan gaya hidup dan pola makan. Obesitas merupakan kondisi terdapat penimbunan lemak tubuh yang berlebihan. Cara yang paling mudah secara medis adalah dengan mengukur indeks massa tubuh (IMT). Indeks massa tubuh menggambarkan kelebihan jaringan lemak di seluruh tubuh yang dapat dihitung dengan membagi berat badan dalam kilogram $(\mathrm{kg})$ dengan tinggi badan dalam meter pangkat dua $\left(m^{2}\right)$. Kriteria obes untuk orang Asia adalah IMT $\geq 25 \mathrm{~kg} / \mathrm{m}^{2} 1.2$. Data dari National Health and Nutrition Examination Survey ke III (NHANES III) menunjukkan bahwa $20 \%$ pria dewasa dan $25 \%$ wanita dewasa Amerika mempunyai indeks massa tubuh (IMT) melebihi $30 \mathrm{~kg} / \mathrm{m}^{2}$, sepertiga lainnya mempunyai indeks massa tubuh (IMT) 25$30 \mathrm{~kg} / \mathrm{m}^{2}$. Obesitas merupakan masalah kesehatan yang memerlukan perhatian khusus karena berkaitan dengan berbagai faktor risiko penyakit seperti diabetes ataupun kardiovaskuler. Obesitas merupakan masalah epidemiologi global serta anc aman serius bagi kesehatan, karena meningkatkan angka morbiditas dan mortalitas 3,4. Obesitas merupakan faktor risiko berkembangnya resistensi insulin dan diabetes melitus tipe 2. Suatu penelitian di Amerika Serikat menyebutkan prevalensi resistensi insulin pada orang obes adalah 59,6\%5. Resistensi insulin merupakan suatu kelainan metabolik yang berdampak negatif, tidak hanya merupakan suatu kelainan yang mendasari diabetes melitus, tetapi juga mendasari sekelompok kelainan kardiovaskuler ${ }^{4}$.

Tumpukan jaringan adiposa pada obesitas memiliki peran biologis, tidak hanya berperan pasif sebagai tempat penyimpanan dan berlangsungnya proses metabolisme trigliserida tetapi juga berperan sebagai kelenjar endokrin yang mensekresi berbagai sitokin dan hormon peptida yang turut berperan dalam pengaturan keseimbangan berat badan dan metabolisme energi ${ }^{4}$. J aringan adiposa merupakan jaringan yang kompleks dan berperan pada proses metabolisme, seperti homeostasis glukosa dan proses inflamasi. Beberapa substansi itu seperti adiponektin, leptin, resistin, Interleukin-6, Tumor Necrosis Factor $\square$ (TNF $\square$ ), Plasminogen Activator Inhibitor I (PAI-1). Resistin diduga mempunyai peran pada terjadinya kondisi resistensi insulin $6,7,8$,

Resistensi insulin didefinisikan sebgai kondisi klinis dengan kemunduran potensi insulin baik endogen maupun eksogen untuk meningkatkan pengambilan glukosa dan penggunaan glukosa oleh sel-sel tubuh. Diagnosa resistensi insulin dapat ditegakkan dengan pengukuran langsung maupun tidak langsung. Pada praktek klinik, pengukuran homeostasis model aseessment (HOMA) merupakan metode yang praktis dan mudah digunakan. Teknik yang sederhana ini dapat menduga sensitivitas insulin dengan rumus dari glukosa darah puasa dan konsentrasi insulin. HOMA-IR $\geq 2,77$ dinyatakan resistensi insulin 9 . 
Resistin sebagai salah satu adipositokin (adipokin) yang disekresi oleh adiposit diduga berperan penting sebagai penghubung antara adiposit dan resistensi insulin dengan cara inhibisi insulin-stimulated glucose uptake dan membloking diferensiasi adiposit. Resistin termasuk kelompok produk gen protein kaya sistein yang disekresikan (small cysteine-rich secreted protein) oleh sel adiposit 10,11,12. Resistin predominan diekspresikan di white adipose tissue (WAT) yang dapat dideteksi di serum. Penelitian awal Steppan et al. 12 menemukan kadar resistin pada sirkulasi meningkat pada mencit obes. Pemberian resistin rekombinan menurunkan toleransi glukosa dan meningkatkan kadar insulin plasma, dan pemberian antibodi antiresistin memperbaiki resistensi insulin. Dari observasi ini resistin menurunkan sensitivitas insulin, hal ini mendukung adanya hubungan antara jaringan adiposa dengan resistensi insulin. Silha et al. ${ }^{13}$ dan Yamauchi et al. ${ }^{14}$ mendukung kadar resistin Iserum lebih tinggi pada subyek obes. Penelitian Lu et al. ${ }^{15}$ memperlihatkan kadar resistin plasma memperlihatkan korelasi positif dengan indeks masa tubuh, kadar glukosa, trigliserida dan indeks resistensi insulin. Kadar resisitin mempunyai koelasi negatif dengan indeks resistensi insulin. Penelitian Courten et al.16 di Pima Indian, memperlihatkan kadar plasma mempunyai korelasi positif dengan indeks masa tubuh, persentase lemak tubuh, tidak berkorelasi dengan resistensi insulin. Tetapi ada beberapa penelitian yang masih kontroversial tentang hubungan antara resistin dengan resistensi insulin pada obesitas. Tujuan dari penelitian ini untuk mengetahui perbedaan kadar resistin pada obes dengan resistensi insulin dan obes tanpa resistensi insulin.

\section{METODE DAN CARA}

Penelitian dilakukan dengan menggunakan rancangan penelitian potong lintang (cross-sectional study). Penelitian dilakukan di Poliklinik Endokrin dan poliklinik General Check Up RSUP Dr. Sardjito Yogyakarta. Waktu penelitian mulai bulan 1 Oktober sampai 30 November 2006. Populasi target adalah orang obes. Populasi terjangkau adalah orang obes yang periksa di Poliklinik Endokrin dan Poliklinik General Check Up RSUP Dr. Sardjito Yogyakarta. Kriteria inklusi subyek penelitian: Penderita obes umur $\geq 22$ tahun dan $\leq 60$ tahun, IMT $\geq 25$ $\mathrm{kg} / \mathrm{m}^{2}$, menyetujui dan menandatangani informed consent. Kriteria eksklusi: diketahui menderita hipertensi, infeksi, kanker, penyakit kardiovaskuler, penyakit hepar (enzim transaminase (alanine aminotransferase dan aspartat aminotransferase) lebih dari 2 kali batas atas nilai normal), pengobatan steroid, pengobatan tiazolidinedione. Estimasi besar sampel dihitung berdasarkan rumus penghitungan sampel untuk penelitian analitik numerik tidak berpasangan. Cara penelitian adalah Subyek yang memenuhi kriteria inklusi dan eksklusi pada saat kontrol yang pertama dipesan untuk datang pada hari yang telah ditentukan. Subyek datang dalam keadaan puasa sedikitnya selama 10 jam. Pada hari yang telah ditentukan data identitas subyek dicatat dalam formulir penelitian dan dilakukan pemeriksaan fisik termasuk tekanan darah, tinggi badan dan berat badan. 
Kemudian dilakukan pengambilan darah vena sebanyak $10 \mathrm{cc}$ untuk pemeriksaan kadar gula darah puasa, gula darah 2 jam sesudah makan, kolesterol total, trigliserida, high density lipoprotein (HDL), low density lipoprotein (LDL), kadar insulin plasma puasa dan kadar resistin. Pemeriksaan sampel darah dilakukan di laboratorium Prodia Yogyakarta. Pengukuran resistensi insulin berdasarkan metode HOMA IR yang dihitung dengan rumus gula darah puasa $X$ plasma insulin puasa / 22,5. HOMA-IR $\geq 2,77$. dinyatakan resistensi insulin. Pengukuran resistin dengan metode ELISA, Biovendor assay, yang mempunyai limit deteksi $0,2 \mathrm{ng} / \mathrm{ml}$ dengan rentang $1-50 \mathrm{ng} / \mathrm{ml}$. Nilai normal resistin 6,39-26,4 $\mathrm{ng} / \mathrm{ml}$. Data disajikan HASIL DAN PE MB AHASAN dalam bentuk rerata dan simpangan baku, median dan interval kepercayaan. Untuk membandingkan rerata kedua kelompok yang terdistribusi normal dengan uji-t tak berpasangan, dan tidak terdistribusi normal dengan uji Mann Whitney $U$. $p<0,05$ dianggap bermakna. Semua ana lisis statistik dilakukan dengan SPSS 15.

Tabel 1. Karakteristik Dasar Subyek Penelitian

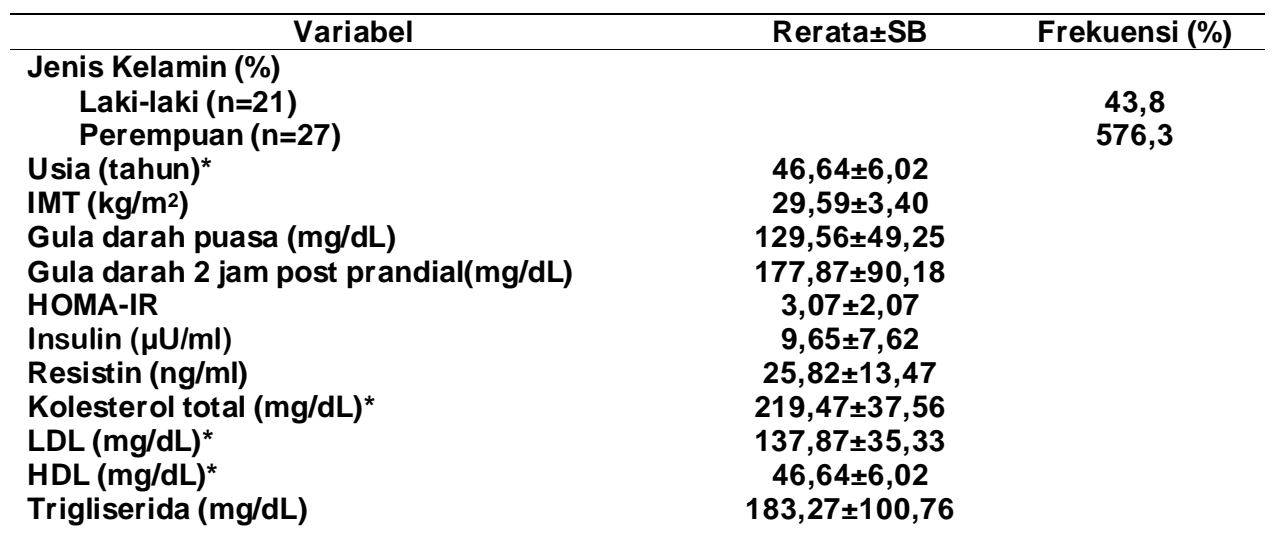

Keterangan: IMT = indeks massa tubuh; SB = simpangan baku; HOMA-IR = homeostasis model assesment insulin resistance; $L D L=$ low density lipoprotein; HDL = high density lipoprotein, $*=$ distribusi tidak normal. 
Tabel 2. Perbandingan Data Klinis dan Laboratoris Kelompok Dengan Resistensi Insulin dan Kelompok Tanpa Resistensi Insulin

\begin{tabular}{|c|c|c|c|c|}
\hline Variabel & $\begin{array}{c}\text { Dengan } \\
\text { Resistensi Insulin } \\
(n=24)\end{array}$ & $\begin{array}{c}\text { Tanpa } \\
\text { Resistensi Insulin } \\
(n=24)\end{array}$ & $\mathbf{P}$ & $95 \%$ IK \\
\hline $\begin{array}{l}\text { Usia (tahun) } \\
\text { J enis kelamin, n (\%) }\end{array}$ & $48,00 \pm 5,56$ & $45,29 \pm 6,28$ & $0,192 *$ & \\
\hline $\begin{array}{l}\text { Laki-laki } \\
\text { Perempuan }\end{array}$ & $\begin{array}{l}10(41,7 \%) \\
14(58,3 \%)\end{array}$ & $\begin{array}{l}11(45,8 \%) \\
13(54,2 \%)\end{array}$ & 0,777 & \\
\hline $\begin{array}{l}\text { IMT }\left(\mathbf{k g} / \mathbf{m}^{2}\right) \\
\text { G DP }(\mathbf{m g} / \mathrm{dL}) \\
\text { G D2J PP (mg/dL) } \\
\text { Insulin }(\mu \mathrm{U} / \mathrm{ml})\end{array}$ & $\begin{array}{c}30,55 \pm 4,11 \\
158,04 \pm 49,26 \\
235,91 \pm 83,96 \\
13,01 \pm 8,87\end{array}$ & $\begin{array}{c}28,64 \pm 2,20 \\
101,08 \pm 28,94 \\
119,84 \pm 50,37 \\
6,29 \pm 2.50\end{array}$ & $\begin{array}{c}0,051 \\
<0,001 \\
<0,001 \\
0,001\end{array}$ & $\begin{array}{c}-3,83-0,01 \\
-80,43--33,48 \\
-156,32-- \\
75,85\end{array}$ \\
\hline $\begin{array}{l}\text { Kolesterol total (mg/dL) } \\
\text { LDL (mg/dL) } \\
\text { HDL (mg/dL) } \\
\text { Trigliserida (mg/dL) } \\
\text { Resistin (na/ml) }\end{array}$ & $\begin{array}{c}223,21 \pm 37,43 \\
135,83 \pm 36,7 \\
52,79 \pm 9,29 \\
209,58 \pm 125,73 \\
27,64 \pm 14,43\end{array}$ & $\begin{array}{c}215,75 \pm 38,10 \\
139,90 \pm 34,56 \\
52,13 \pm 9,14 \\
156,96 \pm 59,13 \\
23,99 \pm 12,45\end{array}$ & $\begin{array}{l}0,571^{*} \\
0,918^{*} \\
0,68 *^{*} \\
0,070 \\
0,375^{*}\end{array}$ & $-10,49--3,90$ \\
\hline
\end{tabular}

Keterangan: IMT = indeks massa tubuh; SB = simpangan baku; IK = interval kepercayaan; GDP = gula darah puasa; GD2JPP = gula darah 2 jam post prandial; HOMA-IR = homeostasis model assesment insulin resistance; LDL = low density lipoprotein; HDL = high density lipoprotein.* Mann Whitney U Test.

Selama penelitian didapatkan sampel penelitian sejumlah 48 subyek obes yang memenuhi kriteria inklusi dan eksklusi yang dapat dianalisis dalam penelitian ini. 24 subyek obes dengan resistensi insulin dan 24 subyek obes tanpa resistensi insulin. Karakteristik dasar subyek penelitian (Tabel 1) mencakup proporsi jenis kelamin subyek dan rerata \pm simpang baku masingmasing variabel yang diteliti. Rerata usia $46,64 \pm 6,02$ tahun dengan rerata IMT $29,59 \pm 3,40 \mathrm{~kg} / \mathrm{m}^{2}$. Dari hasil pemeriksaan laboratorium didapatkan rerata kadar gula darah puasa $129,56 \pm 49,25 \mathrm{mg} / \mathrm{dL}$, kadar gula darah 2 jam post prandial $177,87 \pm 90,18 \mathrm{mg} / \mathrm{dL}$, HOMA-IR 3,07 $\pm 2,07$, kadar insulin 9,65 $\pm 7,62 \mu \mathrm{U} / \mathrm{ml}$, kadar resistin 25,82 $\pm 13,47 \mathrm{pg} / \mathrm{ml}$, kadar trigliserida $183,27 \pm 100,76 \mathrm{mg} / \mathrm{dL}$. Rerata kadar kolesterol total 219,47 $\pm 37,56$ $\mathrm{mg} / \mathrm{dL}$, kadar LDL $137,87 \pm 35,33 \mathrm{mg} / \mathrm{dL}$ dan kadar HDL 46,64 $\pm 6,02 \mathrm{mg} / \mathrm{dL}$.

Pada penelitian ini subyek dikelompokkan menjadi 2 kelompok yaitu kelompok obes dengan resistensi insulin dan kelompok obes tanpa tanpa resistensi insulin. Dari penelitian ini didapatkan 24 orang masuk kelompok obes dengan resistensi insulin (HOMA-IR $>2,77$ ) dan 24 orang yang masuk kelompok obes tanpa resistensi insulin (HOMA-IR $\leq 2,77$ ).

Tabel 2 menunjukan perbandingan variabel klinis dan laboratorium berdasarkan status resistensi insulin. Dapat dilihat bahwa pada kelompok dengan resistensi insulin didapatkan usia yang lebih tua dibanding kelompok yang tidak mengalami resistensi insulin tetapi tidak bermakna secara statistik $(48 \pm 5,56$ tahun dan 45,29 $\pm 6,28$ tahun; $p=0,192$ ). Untuk IMT (indeks massa tubuh), nilai reratanya lebih tinggi pada kelompok yang mengalami resistensi insulin dibanding kelompok yang tidak mengalami resistensi insulin tetapi tidak bermakna secara statistik $(30,55 \pm 4,21$ $\mathrm{kg} / \mathrm{m}^{2}$ dan 28,64 $+2,20 \mathrm{~kg} / \mathrm{m}^{2} ; \mathrm{p}=0,05195 \%$ IK -3,83-0,01). Hasil pemeriksaan 
didapatkan bahwa rerata kadar gula darah puasa, gula darah 2 jam post prandial dan insulin lebih tinggi pada kelompok yang mengalami resistensi insulin dibanding yang tidak mengalami resistensi insulin $(158,04 \pm 49,26 \mathrm{mg} / \mathrm{dL}$ dan $101,08 \pm 28,94 \mathrm{mg} / \mathrm{dL} ; 235,92 \pm 83,96$ $\mathrm{mg} / \mathrm{dL}$ dan $119,84 \pm 50,37 \mathrm{mg} / \mathrm{dL}$; $13,01 \pm 8,82 \mu \mathrm{U} / \mathrm{ml}$ dan $6,29 \pm 2,5 \mu \mathrm{U} / \mathrm{ml}$ secara berurutan), secara statistik berbeda bermakna ( $p<0,001 ; p<0,001$; dan $p=0,001$, secara berurutan).

Rerata kadar kolesterol, LDL, HDL lebih tinggi pada kelompok dengan resistensi insulin dibanding kelompok yang tidak mengalami resistensi insulin $(223,21 \pm 37,43 \mathrm{mg} / \mathrm{dL}$ dan $215,75 \pm 38,10$ $\mathrm{mg} / \mathrm{dL} ; \quad 139,71 \pm 34,69 \mathrm{mg} / \mathrm{dL}$ dan $139,90 \pm 34,56 \mathrm{mg} / \mathrm{dL} ; 52,79 \pm 9,29 \mathrm{mg} / \mathrm{dL}$ dan $52,13 \pm 9,14 \mathrm{mg} / \mathrm{dL}$ secara berturutan) tetapi secara statistik tidak bermakna $(p=0,571 ; p=0,918$ dan $p=0,680$ secara berturutan). Pada kelompok yang mengalami resistensi insulin, rerata kadar trigliserida lebih tinggi dibanding kelompok yang tidak mengalami resistensi insulin $(209,58 \pm 125,7 \mathrm{mg} / \mathrm{dL}$ dan $156,96 \pm 59,13 \mathrm{mg} / \mathrm{dL}$ ), dan bermakna secara statistik $(p=0,007)$. Kadar resistin pada kelompok yang mengalami resistensi insulin lebih tinggi dibandingkan kadar resistin pada kelompok tanpa resistensi insulin $(27,65 \pm 14,44 \mathrm{ng} / \mathrm{ml}$ dan $23,99 \pm 12,45$ $\mathrm{ng} / \mathrm{ml}$ ) tetapi tidak bermakna secara statistik $(p=0,375)$. Pada penelitian ini rerata kadar resistin pada laki-laki $25,06 \pm 16,05 \mathrm{ng} / \mathrm{ml}$ dan rerata kadar resistin pada perempuan $26,41 \pm 11,34$ $\mathrm{ng} / \mathrm{ml}$, dan tidak berbeda bermakna $(p=0,209)$.

Penelitian ini dengan rancangan cross sectional bertujuan untuk mengetahui kadar resistin pada orang obes dengan resistensi insulin dan orang obes tanpa resistensi insulin. Beberapa penelitian terdahulu menyatakan bahwa resistin diduga sebagai faktor yang berperan terhadap resistensi insulin pada obesitas, sehingga kadar resistin pada obes dengan resistensi insulin lebih tinggi pada obes tanpa resistensi insulin. Obesitas merupakan faktor risiko berkembangnya kejadian resistensi insulin sehingga prevalensi obes dengan resistensiinsulin meningkat.. Reynolds dan $\mathrm{He}^{5}$ meneliti prevalensi resistensi insulin pada orang obes sebesar $59,6 \%$. Pada penelitian ini didapatkan rerata IMT sebesar $29,59 \pm 3,40 \mathrm{~kg} / \mathrm{m}^{2}$, berdasarkan kriteria WHO untuk orang Asia termasuk obes I (IMT 25-29,9 kg/m²) dengan risiko morbiditas tingkat sedang. Rerata IMT ini lebih rendah dibandingkan penelitian Silha et al. ${ }^{13}$ yaitu $33,0 \pm 1,3 \mathrm{~kg} / \mathrm{m}^{2}$, S ubyek penelitian perempuan lebih banyak $(56,25 \%)$ dibandingkan laki-laki $(43,75 \%)$, hal ini sesuai dengan penelitian Silha et al. ${ }^{13}$ yang mendapatkan orang obes lebih banyak pada perempuan dibanding lakilaki. Tetapi berbeda dengan penelitian Lu et al. ${ }^{15}$ yang mendapatkan orang obes lebih banyak pada laki-laki dibanding perempuan.

Resistin merupakan salah satu protein adipositokin yang diproduksi oleh jaringan adiposa, kadarnya meningkat pada pasien dengan obesitas dan erat kaitannya dengan kejadian resistensi insulin. Resistin diduga sebagai penghubung antara adiposit dan resistensi insulin dengan cara inhibisi insulin stimulated glucose uptake. Beberapa penelitian terdahulu mendukung bahwa kadar resistin tinggi menginduksi resistensi insulin dan 


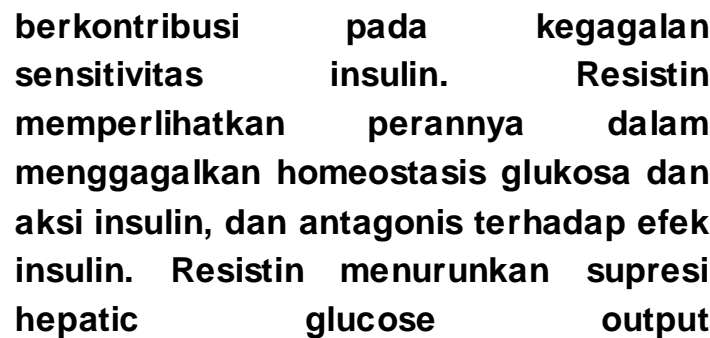
(glukoneogenesis) dan menurunkan kemampuan otot skelet dan adiposa dalam ambilan glukosa ${ }^{12,15}$, Rerata kadar resistin pada seluruh subyek obes pada penelitian ini adalah $25,82 \pm 13,47 \mathrm{ng} / \mathrm{ml}$ Hasil ini lebih rendah dibandingkan penelitian yang dilakukan Silha et al.13 dengan rerata kadar resistin pada subyek obes $28,8 \pm 5,8 \mathrm{ng} / \mathrm{ml}$, tetapi lebih tinggi dibandingkan penelitian Lu et al. ${ }^{15}$ dengan rerata kadar resistin $24,05 \pm 9,07$ $\mathrm{ng} / \mathrm{ml}$.

Pada penelitian ini subyek dikategorikan dua kelompok orang obes berdasarkan HOMA-IR, yaitu kelompok yang mengalami resistensi insulin (HOMA-IR $>2,77$ ) 24 orang dan kelompok yang tidak mengalami resistensi insulin (HOMA-IR $\leq 2,77$ ) 24 orang. Pada penelitian ini kadar resistin pada kelompok resistensi insulin lebih tinggi dibandingkan kadar resistin pada kelompok tanpa resistensi insulin $(27,65 \pm 14,44 \mathrm{ng} / \mathrm{ml}$ dan $23,99 \pm 12,45$ $\mathrm{ng} / \mathrm{ml}$ ) tetapi tidak bermakna secara statistik $(p=0,375)$. Penelitian yang pernah dilakukan adalah korelasi resistin dengan resistensi insulin pada penderita diabetes yang dilakukan Lu et al.15 dengan hasil resistin berkorelasi positif dengan resistensi insulin $(r=0,27$, $p<0,05)$. Silha et al.13 meneliti korelasi resistin dengan resistensi insulin pada obesitas dengan hasil bermakna secara statistik setelah disesuaikan dengan jenis kelamin dan usia $(r=0,513, p<0,001)$.
Beberapa hal yang dapat mempengaruhi kadar resistin adalah inflamasi atau infeksi, hormon glukokortikoid, penggunaan hormon seks misalnya kontrasepsi, penggunaan obat AINS (Antiinflamasi non steroid), penggunaan obat-obatan golongan insulin sensitisizer, ataupun adanya penyakit tiroid.16. Faktor-faktor tersebut ada yang belum dapat dikendalikan dalam penelitian ini.

Pada penelitian ini beberapa variabel dibandingkan antara kelompok obes dengan resistensi insulin dengan kelompok obes tanpa resistensi insulin. Pada variabel kadar gula darah puasa, kadar gula darah 2 jam post prandial, dan kadar insulin menunjukkan perbedaan bermakna $(p<0,001, p<0,001$, dan $p=0,001$ ). Pada individu obes yang mengalami resistensi insulin akan menyebabkan hambatan kerja di insulin baik di hati, otot, maupun jaringan adiposa. Resistensi insulin di hati akan mengaktifkan proses glukoneogenesis sehingga kadar glukosa plasma puasa akan meningkat. Variabel trigliserida menunjukkan perbedaan bermakna dengan $p=0,007$. Pada penderita obes, peningkatan kadar trigliserida dan asam lemak bebas, aktivitasnya memberi kontribusi pada resistensi insulin. Trigliserida akan mengalami hidrolisis oleh enzim lipoprotein lipase yang berasal dari endotel menjadi asam lemak bebas. Asam lemak bebas (Free fatty Acid / FFA) yang tinggi dalam plasma menyebabkan peningkatan glukoneogenesis hepar, penurunan ambilan glukosa otot, sehingga berperan terhadap terjadinya resistensi insulin baik pada otot, hati maupun pankreas ${ }^{\mathbf{1 4}}$. 
Dari penelitian ini kadar resistin pada obes dengan resistensi insulin lebih tinggi dibanding pada obes tanpa resistensi insulin $(27,65 \pm 14,44 \mathrm{ng} / \mathrm{ml}$ dan $23,99 \pm 12,45 \mathrm{ng} / \mathrm{ml})$, tetapi secara statistik tidak ada perbedaaan bermakna ( $p=0,375)$. Hasil yang tidak bermakna ini kemungkinan disebabkan oleh beberapa kelemahan dalam penelitian ini. Beberapa kelemahan pada penelitian ini adalah penelitian menggunakan rancangan penelitian potong lintang (cross sectional study) memberikan keterbatasan dalam menarik kesimpulan sebab akibat karena paparan dan outcome diukur dalam waktu yang bersamaan. Kelemahan yang lain adalah beberapa faktor yang dapat mempengaruhi kadar resistin kurang dapat dikendalikan seperti adalah penggunaan hormon seks misalnya kontrasepsi, penggunaan obat AINS (Antiinflamasi non steroid), ataupun adanya penyakit tiroid. Kadar resistin juga dapat dipengaruhi oleh oleh beberapa agen dan hormon termasuk thiazolidinediones, insulin, TNF alfa, dan growth hormone, hormon gonadal, hormon tiroid, status nutrisi. Resistensi insulin dapat dipengaruhi oleh usia, inaktivitas, asam lemak bebas yang tinggi, dan adipositokin yang lain ${ }^{17}$.

\section{Simpulan}

Hasil penelitian ini didapatkan kadar resistin pada obes dengan resistensi insulin lebih tinggi dibanding pada obes tanpa resistensi insulin, tetapi tidak berbeda bermakna. Perlu dilakukan penelitian lebih lanjut dengan pengendalian yang lebih ketat terhadap beberapa faktor yang berperan terhadap kadar resistin dan resistensi insulin.
Daftar Pustaka

1. Adam, J .M.F. Obesitas dan Diabetes Mellitus Tipe 2 dalam: J.M.F., Adam (ed). Obesitas dan Sindroma Metabolik. Bandung: FK Univeritas Pajajaran. 2006, pp 9-20.

2. Adam, J.M.F. Obesitas, Pengertian, dan Kriteria Diagnosis dalam J .M.F., Adam (ed). Obesitas dan Sindroma Metabolik. Bandung: FK Universitas Pajajaran 2006, pp 1-8

3. Direktorat Bina Gizi Masyarakat Departemen Kesehatan. Overweight dan Obesitas di Indonesia. Jakarta: Departemen Kesehatan Indonesia, 1997

4. Soegondo, S. Obesitas, dalam: A.W. Sudoyo, B., Setiyohadi, L., Alwi, M., Simadibrata, S., dan Setiati, S. (eds) Buku Ajar IImu Penyakit Dalam Edisi IV, Jakarta: Pusat Penerbitan Departemen IImu Penyakit Dalam Fakultas Kedokteran Universitas Indonesia., 2006, pp 50-62

5. Reynolds, K., and $\mathrm{He}$, J. Epidemiology of Metabolic Syndrome. Am J Med Sci, 2005; 330: 273-9

6. Shuldiner, A.R., Yang, R., and Gong, D. Resistin, Obesity, And Insulin Resistance - The Emerging Role of The Adipocyte As An Endocrin Organ. N Engl J Med. 2001; 345(18):1345-6

7. Soeatmadji, D.W. Patogenic Mechanisms of Obesity: New Findings in Resistin in $A_{\text {., }}$ Tjokroprawiro, Hendromartono, A., Sutjahjo, H., Tandra, A., Pranoto, S., Murtiwi, dan S., Adi, (eds). Naskah Lengkap National Obesity 
Symposium I. Surabaya: Perkeni., 2003, pp149-54.

8. Tjokroprawiro, A. Obesity: Capita Selecta 2003 (Map of Fat Cell and Molecular Basis for Clinical Relevance) in A.,Tjokroprawiro, Hendromartono, A., Sutjahjo, H., Tandra, A., Pranoto, S., Murtiwi, S., dan Adi (eds). Naskah Lengkap National Obesity Symposium II. Surabaya : Perkeni. 2003, pp 1-8.

9. Meier, U., and Gressner, A.M. Endocrine Regulation of Energy Metabolism: Review of Pathobiohemical and Clinical Chemical Aspects of Leptin, Ghrelin, Adiponectin and Resistin. Clinical Chemistry. 2004 ; 15 (9): 1511-25,

10. Trayhurn, P., and Wood, I.S. Signalling Role Of Adipose Tissue : Adipokines and Inflammation In Obesity. Biochemical Society Transactions. 2005; 33:1078-81

11. Cefalu, W.T.,. Insulin Resistance: Cellular and Clinical Concepts. Exp Biol Med. 2001;226:13-26

12. Steppan, C.M., Bailey, S.T., Bahat, S., Brown, E.J., Banerjee, R.R., Wright, C.M., Patel, H.R., Ahima, R.S., and Lazar, M.A. The Hormone Resistin Links Obesity to Diabetes. Nature. 2001;409:307-12
13. Silha, J.V., Kresk, M., Skrha, J.V., Sucharda, P., Nyomba, B.L.G., and Murphy, L.J. Plasma Resistin, Adiponectin And Leptin Levels in Lean and Obese Subjects: Correlation With Insulin Resistance. Europ J Endocrinol ; 2003.149: 3315

14. Yamauchi, M.D., Bovenkerk, J.E., J uliar, B.E., Watson, W., Kerr, K., J ones, R., Zhu, Q., and Considine, R.V. Serum Resistin (FIZZ3) Protein is Increased In Obese Humans. J. Clin Endocrinol Metab. 2003;88:5452-5

15. Lu, H.L., Wang, H.W., Wen, Y., Zhang, M.X.,and Lin, H.H. Roles Of Adipocyte Derived Hormone Adiponectin and Resistin in Insulin Resistance of Type 2 Diabetes. World J Gastroenterol. 2006;12(11):1741-51

16. Courten, B.V., Yamauchi, D.W., Considine, R.V., and Tataranni, P.A. High Serum Resistin is Associated With An Increase in Adiposity But Not a Worsening of Insulin Resistance in Pima Indians. Diabetes. 2004;53:1279-84

17. Kusminki, C.M., Mc Ternan, P.G., and Kumar, $S$. Role of Resistin in Obesity, Insulin Resistance and Type II Diabetes. Clinical Science. 2005;109: 243-256 